\title{
CURADORIA E GESTÃO CULTURAL EM DESIGN: UMA ANÁLISE DA BIENAL BRASILEIRA DE DESIGN 2015
}

\author{
Izabela Muniz Ambiel \\ Universidade Estadual Paulista Júlio de Mesquita Filho - UNESP \\ izabela.m.ambiel@gmail.com \\ Mônica Moura \\ Universidade Estadual Paulista Júlio de Mesquita Filho - UNESP \\ monicamoura@faac.unesp.br
}

Resumo: Desde os anos 60 a relação entre curadoria e design vem se estreitando, seja pela criação de novas instituições que promovem o design como cultura ou pelo desenvolvimento do comércio especializado, os curadores e gestores estão ganhando cada vez mais importância tanto em ações culturais e mercadológicas quanto no cenário de criação e desenvolvimento de projeto. Diferente da relação do curador de arte com os artistas/instituições, a relação do curador de design tomou outra postura durante os últimos anos, onde o curador tomou pra si o papel de fomentador do design como cultura, assumindo o design como agente de mudança social e cultural além de, algumas vezes, ser, também, um agente comercial. Muito mais importante que a venda e a geração de negócios de milhões de reais em feiras, o fato de podermos mudar a realidade das pessoas a partir do design é o que tem ganhando os holofotes dos profissionais da área. Eventos espalhados pelo Brasil vêm disseminando o Design Solidário, Inclusivo, Universal e Social tanto na academia quanto no comércio e cultura, atingindo um público diverso, mostrando que bons projetos podem causar grandes impactos em muitas vidas. A Bienal Brasileira de Design de 2015 (BBD 2015) aconteceu em Florianópolis, e foi objeto de estudo para essa pesquisa de iniciação científica que foi desenvolvida a partir de abordagem qualitativa, pesquisa de campo e estudo de caso. O tema "Design para todos" foi o enfoque da BBD 2015, cuja curadoria tinha o objetivo de transitar pelas áreas mais diversas do design, desde o artesanato até o industrial, para mostrar justamente como o design pode melhorar a vida das pessoas e ajudar a superar as dificuldades do dia-a-dia. A pesquisa de campo foi realizada de forma complementar a iniciação, com a atuação da aluna como pesquisadora responsável por São Paulo em estágio na equipe de curadoria do evento, que foi comandada por Adélia Borges e posteriormente por Freddy Van Camp. A intenção inicial era focar grande parte da mostra principal em projetos de Design Inclusivo e Social, que resolvessem bem os problemas cotidianos, focando as pessoas que precisavam de acessibilidade e adaptação para realizar suas tarefas básicas. Procuramos trazer para a mostra objetos que tivessem um bom design, que sanassem essas 
necessidades funcionais e que também associassem boa forma e função afim de dar mais autonomia para as pessoas assistidas pelos projetos. Descobrimos muitos projetos de excelência espalhados pelo Brasil que levavam o "Design para todos" nas mais diversas áreas, dando destaque para os projetos de produto que apresentavam alto nível de complexidade e inovação, desde a área da saúde até decoração, esses objetos estavam representando uma nova postura projetual, mais consciente desse todo que envolve o projeto. As atividades desenvolvidas junto à equipe de curadoria do evento tiveram uma grande contribuição para a pesquisa de iniciação, dando uma faceta prática do ofício antes só estudado por observação de outros casos.

Palavras-chave: Design, Curadoria, Gestão Cultural 